\title{
CHEMONUCLEOLYSIS IN LUMBAR DISC HERNIATION: A META-ANALYSIS
}

José Mauro Cardoso Couto, Euclides Ayres de Castilho, Paulo Rossi Menezes

Couto JMC, Castilho EA de, Menezes PR. Chemonucleolysis in lumbar disc herniation: a meta-analysis. Clinics. 2007;62(2):175-80.

PURPOSE: To carry out a systematic review and meta-analysis of the efficacy of chemonucleolysis in the treatment of lumbar disc herniation.

METHODS: Clinical trials were selected from 3 electronic databases (The Cochrane Controlled Trials Register, MEDLINE, and EMBASE). Data were analyzed with the software STATA, using the meta command.

RESULTS: Twenty-two clinical trials were eligible. For chemonucleolysis versus placebo, the summary risk ratio estimate for pain relief as outcome was 1.51 (95\% CI: 1.27-1.80). The summary estimate was 1.07 (95\% CI: 0.95-1.20) for the comparison between chymopapain and collagenase. Regarding chemonucleolysis with chymopapain versus surgery, the fixed-effect summary estimate of effect for pain relief was 0.93 (95\% CI: 0.88-0.98) with surgery as the reference group. In this case, heterogeneity was statistically significant.

CONCLUSIONS: Chemonucleolysis with chymopapain was superior to placebo and was as effective as collagenase in the treatment of lumbar disc prolapse. Results for studies comparing chemonucleolysis with surgery were heterogeneous, making it difficult to interpret the summary measure of effect.

KEYWORDS: Chemonucleolysis. Chymopapain. Systematic review. Meta-analysis. Lumbar disc herniation.

\section{INTRODUCTION}

Surgery to treat lumbar disc prolapse was introduced in $1934,{ }^{1}$ and ever since it has been considered as the main treatment modality when conservative treatment has failed. ${ }^{2}$ However, the therapeutic efficacy of surgical intervention has been a concern, considering that $20 \%$ of the patients are still in pain after surgery, ${ }^{3}$ and that $7 \%$ to $15 \%$ of the patients undergoing discectomy develop the syndrome of failure of the lumbar surgery. ${ }^{4}$ Alternative techniques have been developed and tested, and chemonucleolysis, which refers to the use of chymopapain for enzymatic lysis of the nucleus disc, has been among the most relevant. This technique was first described by Smith in $1964^{5}$ and is the least invasive

Department of Preventive Medicine, São Paulo University Medical School São Paulo/SP, Brazil.

Email: castil@usp.br

Received for publication on October 24, 2006.

Accepted for publication on December 05, 2006. technique for lumbar disc herniation, presenting lower rates of complications in comparison with discectomy. ${ }^{6}$ According to some authors, fewer days in the hospital was found for patients treated with chemonucleolysis, when compared to traditional surgery, ${ }^{7,8}$ which augmented the considerable cost savings. ${ }^{9-12}$ In a prospective study with a follow-up of at least 5 years, among 112 patients treated by chemonucleolysis, $83 \%$ had excellent/good results, $10 \%$ were unchanged, and $8 \%$ were worse after chemonucleolysis. ${ }^{13}$ Nevertheless, an increased global cost was observed if a conventional surgery was needed following failure to improve after an initial chemonucleolysis. ${ }^{14}$ Some studies have shown superior efficacy of chemonucleolysis with chymopapain, as compared with placebo, ${ }^{15-17}$ but there are conflicting results. ${ }^{18}$ In a systematic review of surgical procedures for lumbar disc prolapse that included studies published until 1999, discectomy presented better efficacy than chemonucleolysis with chymopapain, which produced better outcomes than placebo. ${ }^{17}$ However, 
there was evidence of heterogeneity of results between studies, which makes the summary effect measure of the metaanalysis questionable. Chymopapain has been substituted for collagenase by some physicians due to side effects of collagenase, mainly allergic reactions. ${ }^{19,20}$ The aim of the present study was to carry out a systematic review and meta-analysis of the efficacy of chemonucleolysis in the treatment of lumbar disc herniation.

\section{METHODS}

This project was approved by the local Internal Review Board.

\section{Selection of studies and search strategy}

Studies eligible for inclusion in this systematic review had the following characteristics: they were randomized and nonrandomized clinical trials of interventions using chemonucleolysis with chymopapain or collagenase versus placebo or surgery; involved patients of any age with clinical symptoms compatible with lumbar disc herniation with sciatic pain who underwent computerized tomography (CT), magnetic resonance imaging (MRI), or myelography; reported relief of pain as determined by any method as the endpoint of interest; reported the number/proportion of positive results; and published in any language.

Three electronic databases were searched, covering the period from January 1966 through June 2003: the Cochrane Controlled Trials Register, MEDLINE, and EMBASE. Reference lists of studies found in the database search and tables of contents of specialized journals were also checked. The search terms in MEDLINE were: INTERVERTEBRAL-DISK-CHEMOLYSIS, CHYMOPAPAIN, DISCASE, CHYMODIACTIN, NUKLEOLYSIN, CHEMONUCLEOLYSIS, INTERVERTEBRAL near DISK near CHEMOLYSIS, INTERVERTEBRAL-DISK-DISPLACEMENT, SLIPPED near (DISC or DISCS or DISK or DISKS), DISPLACE* near (DISC or DISCS or DISK or DISKS), PROLAP* near (DISC or DISCS or DISK or DISKS), HERNIATED near NUCLEUS near PULPOSUS, DISCECTOMY or DISKECTOMY, PERCUTANEOUS near* NUCLEOLYSIS, ENZYME* it THERAPEUTICUSES, ENZYME near INJECTION, (INTRADISC* or INTRADISK*) near (STEROID* or TRIAMCINOLONE), COLLAGENASE*, SCIATICA, BACK-PAIN, LOWBACK-PAIN, TAIL-EQUINE, TAIL near COMPRESS*.

\section{Quality assessment and data extraction}

Studies were classified according to the criteria of qual- ity given by Jadad's scores ${ }^{21}$ and by the classification of The Cochrane Collaborative Group. ${ }^{22}$ The evaluation of the methodological quality of the studies that involved surgery was accomplished exclusively with the Cochrane scale, which does not included blindness, a condition that cannot be fulfilled in the cases of surgery. Assessment of study quality included whether there was randomization, blinding, assessment of time from intervention to outcome, report of losses to follow-up, and use of standardized assessment of outcome. Study quality was assessed by 2 independent raters (JMCC and EAC), and discrepancies in ratings were resolved by consensus between the raters. Data were also independently extracted from the studies by 2 of the authors (JMCC and EAC), and disagreements were resolved by consensus between them.

\section{Statistical analysis}

Data were analyzed with the software STATA version 8.0, using the meta command (StataCorp, 200x). For each study, a risk ratio and its $95 \%$ confidence interval were calculated. Pooled estimates were calculated with fixed effect estimates, using inverse-variance weighting. When the heterogeneity test yielded a $P$ value $<0.1$, a new summary measure was then obtained using random-effects models for binary outcomes. Possibility of publication bias was analyzed with the funnel plot graph.

\section{RESULTS}

The database search identified 1023 articles (600 in MEDLINE, 394 in EMBASE, and 29 in the Cochrane database), and search of the bibliographic references yielded an additional 21 publications. Of these, 22 were clinical trials involving chemonucleosis as one of the modalities of treatment for lumbar disc herniation (Figure 1). One of such trials was then excluded because it was not possible to extract data for the meta-analysis, and 1 article included 2 studies.

Chemonucleolysis versus placebo was compared in 5 studies published in 1978 through 1988 (Table 1). Sample sizes ranged from 39 to 136 . All studies had random allocation and blinding regarding patient grouping. The length of follow-up varied from 3 months to 2 years. All studies had good quality scores according to both Cochrane and Jadad criteria. The summary risk ratio estimate for pain relief as the outcome was 1.51 (95\% CI: 1.27-1.80), favoring chemonucleolysis (Figure 2). The summary estimate did not vary when each of the 5 studies was excluded 1 at a time.

Chemolucleolysis with chemopapain versus collagenase was compared in 4 studies published in 1987 through 2001 
(Table 2). Sample sizes varied from 83 to 164 and there was random allocation to groups in all 4 studies, but there was no information on blinding. Cochrane and Jadad scores

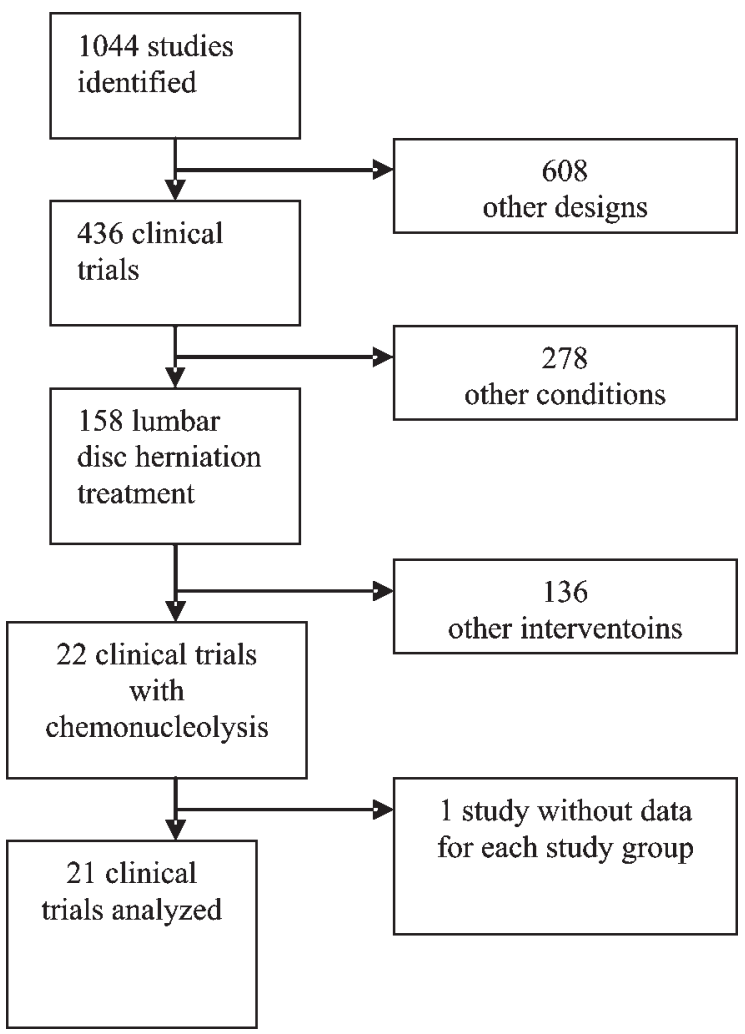

Figure 1 - Search results of clinical trials comparing chemonucleolysis with placebo, collagenase, or surgery in the treatment of lumbar disc herniation. for all 4 studies were $\mathrm{C}$ and 3, respectively. Risk ratios for pain relief, comparing use of chymopapain compared to collagenase varied from 0.94 to 1.38 , yielding a summary estimate of 1.07 (95\% CI: 0.95-1.20, Figure 2).

Chemonucleolysis versus surgery was compared in 12 studies published in 1973 through 1996 (Table 3). Sample sizes varied from 29 to 358 participants. There was random allocation to groups in 6 studies, systematic allocation was used in 2 studies, and participant's choice was used in 3 studies. One study did not give information on the allocation method used. There was no blinding in all but one study. Cochrane scores were $\mathrm{C}$ for all 12 studies, and Jadad's scores varied from 1 to 3 . The fixed-effects summary estimate of effect for pain relief as the outcome and surgery as the reference group was 0.93 (95\% CI: 0.88 0.98), Figure 2). However, the heterogeneity test had a $P$ value $<0.10$, suggesting a higher-than-chance variability of estimates between studies. A random-effects summary estimate was then calculated as 0.9 (95\% CI: 0.8-1.0). Chemonucleolysis was found to be superior to surgery in 3 studies, but only in 1 study was the difference statistically significant, whereas in 5 out of the 9 studies favoring surgery, the difference was statistically significant. For those studies showing superiority of chemonucleolysis, when the summary measure of effect was calculated with the exclusion of 1 study at a time, a strong contribution of the study by Nordby was observed, with a risk ratio of 1.57. The funnel plot analysis suggested the possibility of publication bias (Figure 3).

Table 1 - Clinical trials of chemonucleolysis versus placebo

\begin{tabular}{|c|c|c|c|c|c|c|c|c|c|c|c|c|}
\hline Trial & $\begin{array}{c}\text { Publication } \\
\text { year }\end{array}$ & $\begin{array}{l}\text { Study } \\
\text { country }\end{array}$ & $\begin{array}{l}\text { Number of } \\
\text { individuals }\end{array}$ & $\begin{array}{l}\text { Age }(\mathrm{yr}) \\
\text { range }\end{array}$ & Allocation & Blinding & $\begin{array}{l}\text { Losses to } \\
\text { follow-up }\end{array}$ & $\begin{array}{l}\text { Assestment } \\
\text { of outcome }\end{array}$ & $\begin{array}{l}\text { Length of } \\
\text { follow-up }\end{array}$ & $\begin{array}{l}\text { Jadad } \\
\text { score }\end{array}$ & $\begin{array}{c}\text { Cochrane } \\
\text { score }\end{array}$ & $\begin{array}{l}\text { Chymopapain } \\
\text { (IU) }\end{array}$ \\
\hline Martins $^{23}$ & 1978 & USA & 66 & $18-65$ & random & yes & $\ldots$ & questionnaire & 6 months & 9 & $\mathrm{C}$ & 4000 \\
\hline Javid $^{16}$ & 1983 & USA & 108 & $18-60$ & random & yes & $\ldots$ & $\begin{array}{c}\text { clinical } \\
\text { examination } \\
+ \text { questionnaire }\end{array}$ & 6 months & 3 & $\mathrm{C}$ & 4000 \\
\hline Fraser $^{15}$ & 1984 & Australia & 60 & $19-69$ & random & yes & $\ldots$ & patient views & 3 years & 3 & $\mathrm{C}$ & 4000 \\
\hline Feldman $^{24}$ & 1986 & France & 39 & $21-77$ & random & yes & $\ldots$ & $\begin{array}{l}\text { questionnaire }+ \\
\text { analogic visual } \\
\text { scale }\end{array}$ & 5 years & 3 & $\mathrm{C}$ & 4000 \\
\hline Dabezies $^{7}$ & 1988 & USA & 136 & $18-70$ & random & yes & 10 & questionnaire & 6 months & 5 & A & 3000 \\
\hline
\end{tabular}

Table 2 - Clinical trials of chemonucleolysis versus collagenase

\begin{tabular}{|c|c|c|c|c|c|c|c|c|c|c|c|c|}
\hline Trial & $\begin{array}{c}\text { Publication } \\
\text { year }\end{array}$ & $\begin{array}{l}\text { Study } \\
\text { country }\end{array}$ & $\begin{array}{l}\text { Number of } \\
\text { individuals }\end{array}$ & $\begin{array}{l}\text { Age }(y r) \\
\text { range }\end{array}$ & Allocation & Blinding & $\begin{array}{l}\text { Losses to } \\
\text { follow-up }\end{array}$ & $\begin{array}{l}\text { Assestment } \\
\text { of outcome }\end{array}$ & $\begin{array}{l}\text { Length of } \\
\text { follow-up }\end{array}$ & $\begin{array}{l}\text { Jadad } \\
\text { score }\end{array}$ & $\begin{array}{c}\text { Cochrane } \\
\text { score }\end{array}$ & $\begin{array}{l}\text { Chymopapain } \\
\text { (IU) }\end{array}$ \\
\hline *Hedtmann ${ }^{25}$ & 1987 & Germany & 164 & $20-60$ & random & $\ldots$ & $\ldots$ & McNab criteria & 6 months & 3 & $\mathrm{C}$ & 4000 \\
\hline Hedtmann $n^{25}$ & 1987 & Germany & 86 & $20-60$ & random & $\ldots$ & $\ldots$ & $\begin{array}{l}\text { score+analogic } \\
\text { visual scale }\end{array}$ & 6 months & 3 & $\mathrm{C}$ & 4000 \\
\hline Hedtmann $^{26}$ & 1992 & Germany & 100 & $\ldots$ & random & $\ldots$ & $\ldots$ & $\begin{array}{l}\text { good/fair/poor } \\
\text { criteria }\end{array}$ & 3 years & 3 & $\mathrm{C}$ & 4000 \\
\hline Wittenberg ${ }^{27}$ & 2001 & Germany & 100 & $20-60$ & random & $\ldots$ & 16 & $\begin{array}{l}\text { good/fair/poor } \\
\text { criteria }\end{array}$ & 5 years & 3 & $\mathrm{C}$ & 4000 \\
\hline
\end{tabular}




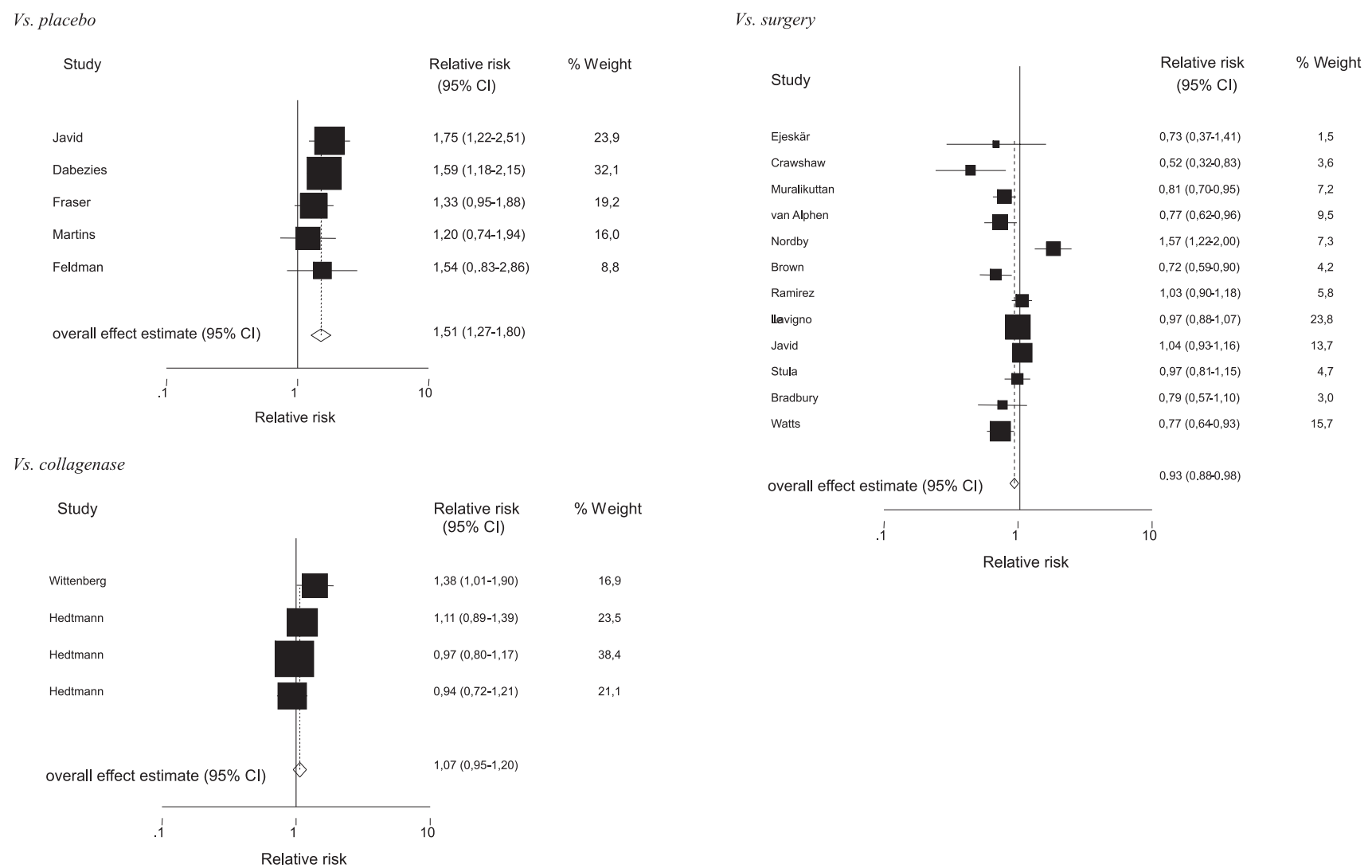

Figure 2 - Forest plots with results of individual studies and summary effect estimates for chemonucleolysis versus placebo, collagenase, and surgery.

Table 3 - Clinical trials of chemonucleolysis versus surgery

\begin{tabular}{|c|c|c|c|c|c|c|c|c|c|c|c|}
\hline Trial & $\begin{array}{c}\text { Publication } \\
\text { year }\end{array}$ & $\begin{array}{l}\text { Study } \\
\text { country }\end{array}$ & $\begin{array}{l}\text { Number of } \\
\text { individuals }\end{array}$ & $\begin{array}{l}\text { Age }(\mathrm{yr}) \\
\text { range }\end{array}$ & Allocation & $\begin{array}{l}\text { Losses to } \\
\text { follow-up }\end{array}$ & $\begin{array}{l}\text { Assestment } \\
\text { of outcome }\end{array}$ & $\begin{array}{l}\text { Length of } \\
\text { follow-up }\end{array}$ & $\begin{array}{l}\text { Jadad } \\
\text { score }\end{array}$ & $\begin{array}{l}\text { Cochrane } \\
\text { score }\end{array}$ & $\begin{array}{l}\text { Chymopapain } \\
\text { (IU) }\end{array}$ \\
\hline Nordby ${ }^{9}$ & 1973 & USA & 191 & $\ldots$ & $\ldots$ & 9 & $\mathrm{McNab}$ criteria & & 1 & $\mathrm{C}$ & $2000-4000$ \\
\hline Watts ${ }^{28}$ & 1975 & USA & 274 & $\ldots$ & consecutive cases & $\ldots$ & clinical examination & 3 months & 2 & $\mathrm{C}$ & 4000 \\
\hline 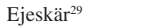 & 1983 & Sweden & 29 & $19-73$ & random & $\ldots$ & questionnaire & 1 year & 3 & $\mathrm{C}$ & 4000 \\
\hline Crawshaw ${ }^{30}$ & 1984 & England & 52 & $\ldots$ & random & 2 & $\begin{array}{c}\text { clinical examination }+ \\
\text { questionnaire }+ \text { analogic } \\
\text { visual scale }\end{array}$ & 1 year & 3 & $\mathrm{C}$ & 4000 \\
\hline Ramirez $^{11}$ & 1985 & USA & 80 & $16-76$ & patient's option & $\ldots$ & & $\ldots$ & 1 & $\mathrm{C}$ & \\
\hline Lavignnolle $^{31}$ & 1987 & France & 358 & $\ldots$ & random & $\ldots$ & McNab criteria & $\ldots$ & 3 & $\mathrm{C}$ & 4000 \\
\hline Brown $^{32}$ & 1989 & USA & 70 & $\ldots$ & patient's option & 11 & pain scale $0-100$ & 3 months & 1 & $\mathrm{C}$ & $\ldots$ \\
\hline van Alphen ${ }^{33}$ & 1989 & Netherlands & 151 & $18-45$ & random & $\ldots$ & patient views & 1 year & 3 & $\mathrm{C}$ & 4000 \\
\hline Stula $^{34}$ & 1990 & Switzerland & 69 & $22-54$ & random & $\ldots$ & $\ldots$ & $\ldots$ & 3 & $\mathrm{C}$ & $\ldots$ \\
\hline Muralikuttan $^{35}$ & 1991 & North Ireland & 92 & $19-60$ & random & $\ldots$ & pain scale $0-100+$ score & 1 year & 3 & $\mathrm{C}$ & 4000 \\
\hline Javid $^{16}$ & 1995 & USA & 200 & $17-72$ & $\begin{array}{c}\text { patient's option + } \\
\text { surgery in no } \\
\text { contiguous herniation }\end{array}$ & $\cdots$ & patient views & 6 months & 1 & $\mathrm{C}$ & 3000 \\
\hline Bradbury ${ }^{36}$ & 1996 & England & 60 & $13-19$ & consecutive cases & 2 & $\begin{array}{c}\text { analogic visual scale }+ \\
\text { questionnaire (St. Thomas) }\end{array}$ & 1 year & 2 & $\mathrm{C}$ & $2000-4000$ \\
\hline
\end{tabular}

= not mentioned

\section{DISCUSSION}

In the present systematic review with meta-analysis, chemonucleolysis with chymopapain was shown to be superior to placebo and was as effective as collagenase in the treatment of lumbar disk herniation. Results for studies comparing chemonucleolysis with surgery were heterogeneous, making it difficult to interpret the summary measure of effect, which showed both options to be equivalent in their effectiveness.

The number of studies comparing chemonucleolysis against placebo and chemonucleolysis against collagenase were low, leading to a lack of statistical power in the tests of heterogeneity of estimates. Nevertheless, by visual inspection and by recalculating summary measures excluding 1 study at a time, no sign of heterogeneity was found. The low number of studies also made it difficult to assess any possibility of publication bias using the funnel plot strategy. 


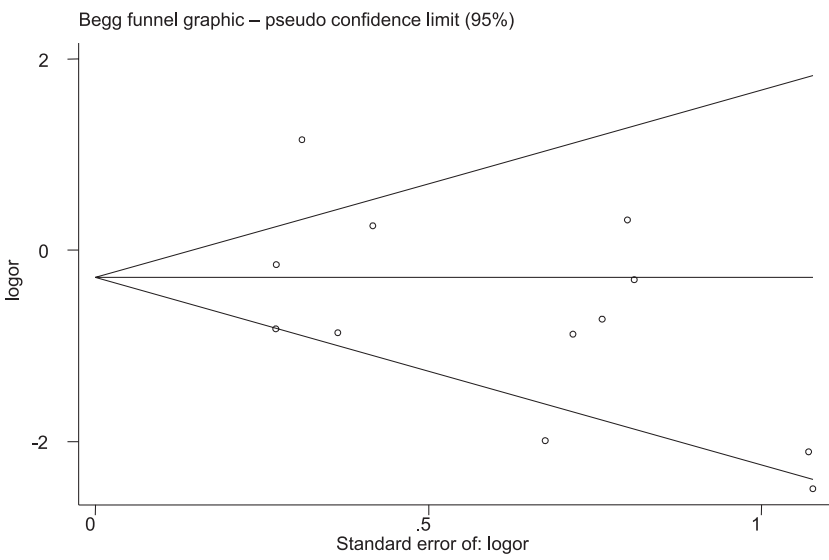

Figure 3 - Funnel plot for clinical trials comparing chemonucleolysis vs. surgery (negative log OR favors surgery)
However, quality scores for selected studies comparing chemonucleolysis against placebo were high, supporting the conclusion that chemonucleolysis with chymopapain is effective in reducing the pain caused by lumbar disc herniation.

\section{ACKNOWLEDGMENTS}

We thank Dr. Evandro S. Freire Countinho of the Oswaldo Cruz Foundation for his contribution to the study. JMCC was supported by the National Council for Scientific and Technological Development - CNPq.

\section{RESUMO}

Couto JMC, Castilho EA de, Menezes PR. Quimonucleólise em hernia de disco lombar: metanálise. Clinics. 2007;62(2):175-80.

OBJETIVO: Avaliar a eficácia da quimonucleólise no tratamento da hérnia de disco lombar por meio de uma metanálise de ensaios clínicos.

MÉTODOS: Os ensaios clínicos foram selecionados de três bases de dados eletrônicas( Cochrane, MEDLINE, e EMBASE). Os dados foram analisados por intermédio do aplicativo STATA, com o comando meta.

RESULTADOS: trabalhamos com 22 ensaios clínicos. Para a comparação entre quimonucleólise e placebo, a estimativa da razão de riscos, tendo melhora da dor como desfecho, foi de 1,51 (I 95\% C: 1,27-1,80). Aquela medida foi de 1,07 (I 95\% C: 0,95-1,20) para a comparação entre quimopapaína e colagenase. Em um modelo de efeitos fixos, a razão de risco, para melhora da dor, foi 0,93 (I 95\% C: 0,88-0,98), tendo a discectomia como grupo de referência. Nesse caso, um teste de heterogeneidade foi considerado estatisticamente significante.

CONCLUSÕES: a eficácia da quimonucleólise foi superior à do placebo e semelhante à da colagenase. Os resultados dos estudos referentes à comparação entre quimonucleólise e cirurgia foram heterogêneos, o que implica interpretação não-trivial da medida de efeito.

UNITERMOS: Quimonucleólise. Quimopapaína. Revisão sistemática. Metanálise. Hérnia de disco lombar.

\section{REFERENCES}

1. Mixter WJ, Barr JS. Rupture of the intervertebral disc with involvement of the spinal canal. New Eng J Med. 1934;211:208-15.

2. Errico TJ, Fardon DF, Lowell TD. Open discectomy as treatment for herniated nucleus pulposus of the lumbar spine. Spine. 1995;20:182933.

3. Kostelianetz M, Espersen JO, Halaburt H, Miletic T. Predictive value of clinical and surgical findings in patients with lumbago-sciatica. A prospective study (Part I). Acta Neurochir (Wien). 1984;73:67-76.

4. Markwalder TM, Battaglia M. Failed back surgery syndrome. Part II: Surgical techniques, implant choice, and operative results in 171 patients with instability of the lumbar spine. Acta Neurochir (Wien). 1993:123:129-34
5. Smith L. Enzyme dissolution of the nucleus pulposus in human. JAMA. 1964;187:177-80

6. Bouillet R. Treatment of sciatica, a comparative survey of complications of surgical treatment and nucleolysis with chymopapain. Clin Orthop Relat Res. 1990;251:144-52.

7. Dabezies EJ, Brunet M. Chemonucleolysis versus laminectomy. Orthopaedics. 1978;1:26-9.

8. Leavitt F, Garron DC, Whisler WW, D'Angelo CM. A comparison of patients treated by chymopapain and laminectomy for low back pain using a multidimensional pain scale. Clin Orthop Relat Res. 1980;146:136-43. 
9. Nordby EJ, Lucas GL. A comparative analysis of lumbar disc disease treated by laminectomy or chemonucleolysis. Clin Orthop Relat Res. 1973;90:119-29.

10. Goldstein G, Gross PF. The Treatment of herniated disc in Australia: Cost and benefits of intradiscal injection of chymopapain and surgery. Aust Fam Physician. 1985;14:1179-90.

11. Ramirez LF, Javid MJ. Cost effectiveness of chemonucleolysis versus laminectomy in the treatment of herniated nucleus pulposus. Spine. 1985;10:363-7.

12. Simmons JW, Nordby, EJ, Hadjipavlou AG. Chemonucleolysis: the state of the art. Euro Spine J. 2001;10:192-202.

13. Guha AR, Debnath UK, D'Souza S.Chemonucleolysis revisited: a prospective outcome study in symptomatic lumbar disc prolapse. J Spinal Disord Tech. 2006;19:167-70.

14. Norton WL. Chemonucleolysis versus surgical discectomy. Spine. $1986 ; 11: 440-3$

15. Fraser RD. Chymopapain for treatment of intervertebral disc herniation. Spine 1982;7:608-12.

16. Javid MJ, Nordby EJ, Ford LT, Hejna WJ, Wishler WW, Burton C et al. Safety and efficacy of chymopapain (Chymodiactin) in herniated nucleus pulposus with sciatica. JAMA. 1983;249:2489-94.

17. Gibson JNA, Grant IC, Waddell G. Surgery for lumbar disc prolapse. Cochrane Database Syst Rev. 2000;(2):CD001350.

18. Maroon JC, Abla A. Microdiscectomy versus chemonucleolysis. Neurosurgery. 1985;16:644-9.

19. Sussman BJ. Injections of collagenase in the treatment of herniated lumbar disc. JAMA. 1981;245:730.

20. Bromley JW, Gomez JG. Lumbar intervertebral discolysis with collagenase. Spine. 1983;8:322.

21. Jadad AR, Moore RA, Carrol D, Jenkinson C, Reybolds DJM, Gavaghan DJ et al. Assessing the quality of reports of randomized clinical trials: is blinding necessary? Control Clin Trials. 1996;17:1-12.

22. Cochrane Controlled Trials Register. In: Cochrane collaboration: Cochrane Library. Issue 1. Oxford: Update Software. 2000.

23. Martins AN, Ramirez A, Johnston J, Schwestschenau PR. Double-blind evaluation of chemonucleolysis for herniated lumbar discs. J Neurosurg. 1978;49:816-27.
24. Feldman J, Menkès CJ, Pallardy G, Chevrot A, Horreard P, Zenny JC, et al. Ėtude en double-aveugle du traitment de la lombosciatique discale par chimionucléolyse. Rev Rhum. 1986;53:147-52.

25. Hedtmann A, Steffen R, Krämer J. Prospective comparative study of intradiscal high-dose and low-dose collagenase versus chymopapain. Spine. 1987;12:388-92.

26. Hedtmann A, Fett H, Steffen R, Krämer J. Chemonukleolyse mit chymopapain und kollagenase. Z Orthop Ihre Grenzgeb. 1992;130:3644 .

27. Wittenberg RH, Oppel S, Rubenthaler FA, Steffen R. Five-year results from chemonucleolysis with chymopapain or collagenase: a prospective randomized study. Spine. 2001;26:1835-41.

28. Watts C, Hutchison G, Stern J, Clark K. Comparison of intervertebral disc disease treatment by chymopapain injection and open surgery. J Neurosurg. 1975;42:397-400.

29. Ejeskär A, Nachemson A, Herberts P, Lysell E, Andersson G, Irstam L et al. Surgery versus chemonucleolysis for herniated lumbar discs: a prospective study with random assignment. Clin Orthop Relat Res. $1983 ; 174: 236-42$.

30. Crawshaw C, Frazer AM, Merriam WF, Mulholland RC, Webb JK. A comparison of surgery and chemonucleolysis in the treatment of sciatica: a prospective randomized trial. Spine. 1984;9:195-8.

31. Lavignolle B, Vital JM, Baulny D, Grenier F, Catagnera L. Etudes Comparees de la chirurgie et de la chimonucleolyse dans le traitement de la sciatique par hernie discale. Acta Orthop Belg. 1987;53:244-9.

32. Brown MD, Tompkins J. Pain response post-chemonucleolysis or disc excision. Spine. 1989;14:321-6.

33. van Alphen HAM, Braakamn R, Bezemer PD, Broere G, Berfelo MW Chemonucleolysis versus discectomy: a randomized multicenter trial. J Neurosurg. 1989;70:869-75.

34. Stula D. Chemonukleolyse mit chymopapain bei der lumbalen diskushernie: randomisierte vergleichstudie mit operierten patienten Neurochirurgia( Stuttg). 1990;33:169-72.

35. Muralikuttan KP, Hamilton A, Kernoahn WG, Mollan RAB, Adair IV A prospective randomized trial of chemonucleolysis and conventional disc surgery in single level lumbar disc herniation. Spine. 1992;17:381-

36. Bradbury N, Wilson LF, Mulholland RC. Adolescent disc protrusions: a long-term follow-up of surgery compared to chymopapain. Spine. $1996 ; 21: 372-7$ 